\title{
Extraction of Lead, Cadmium and Nickel from Contaminated Soil Using Acetic Acid
}

\author{
Hatem Asal Gzar'1, Awatif S. Abdul-Hameed ${ }^{2}$, Asmaa Younus Yahya ${ }^{2}$ \\ ${ }^{1}$ Civil Engineering Department, College of Engineering, University of Wasit, Wasit, Iraq \\ ${ }^{2}$ Civil Engineering Department, College of Engineering, University of Baghdad, Baghdad, Iraq \\ Email: hatam asal@yahoo.com
}

Received 18 April 2014; revised 18 May 2014; accepted 25 May 2014

Copyright (C) 2014 by authors and Scientific Research Publishing Inc. This work is licensed under the Creative Commons Attribution International License (CC BY). http://creativecommons.org/licenses/by/4.0/

(c) (i) Open Access

\begin{abstract}
The accumulation of heavy metals in soil is a serious environmental problem. It is well known that heavy metals have an affinity for different compartments of soil. The risk associated with the presence of metals in soil is the ability of their transfer in water or plants. In the present research, batch extraction experiments were conducted using acetic acid (AA) as an extractant solution at various concentrations and contact times to determine the best conditions of soil washing process to achieve high heavy metal removal efficiencies. AA was investigated for its applicability for the removal of lead, cadmium and nickel from soil. Batch soil washing experiments were performed on $1.0 \mathrm{~g}$ portions of the spiked soil using different concentrations $(0.001,0.005,0.01,0.05$, and 0.1 mol/L) of AA ( $\left.\mathrm{CH}_{3} \mathrm{COOH}\right)$ with solid: liquid ratio of 1:10. The results showed that AA extracted greater $\mathrm{Pb}$ than $\mathrm{Cd}$ and $\mathrm{Ni}$. The extraction was carried out with shaking times from 15 to $180 \mathrm{~min}$. The removal percentage of $\mathrm{Pb}$ varies from $42.2 \%-100 \%$ and $\mathrm{Cd}$ from $5.2 \%-31.1 \%$ with increasing concentration of $\mathrm{AA}$, while the removal efficiency of Ni was not exceeded about $1 \%$. Comparing with $\mathrm{Pb}$ and $\mathrm{Cd}$, the removal efficiency of $\mathrm{Ni}$ was very low; this means that the solubility of $\mathrm{Ni}$ in $\mathrm{AA}$ was very low. It was found that $0.1 \mathrm{~mol} / \mathrm{L}$ AA for soil washing was effective in removing absorbed $\mathrm{Pb}$ from contaminated soil (100\% efficiency) at time $15 \mathrm{~min}$. While the efficiency reaching $100 \%$ with washing solution of 0.05 and $0.01 \mathrm{~mol} / \mathrm{L}$ at times 120 and $180 \mathrm{~min}$, respectively. The efficiencies of $\mathrm{Cd}$ and $\mathrm{Ni}$ extraction were improved when $1 \mathrm{~mol} / \mathrm{L}$ of $\mathrm{AA}$ solution was used $(41.3 \%$ to $70.6 \%$ for Cd and $16.3 \%$ to $23.3 \%$ for $\mathrm{Ni}$ ).
\end{abstract}

\section{Keywords}

Contaminated Soil, Soil Washing, Extraction, Organic Acid, Heavy Metals

\section{Introduction}

The contamination of soils with heavy metals is a major environmental problem throughout the world, which 
may threaten ecosystems and human health [1]. Toxic metals are present in various chemical forms in soils, and exhibit different physical and chemical behaviors in terms of chemical interactions, mobility, biological availability and potential toxicity [2]. Chemical speciation plays a vital role in the solubility and potential bioavailability of metals in soils. Unlike organic compounds, toxic metals are not degradable in the environment, and can persist in soils for decades or even centuries. The contamination of soils by metals can have long-term environmental and health implications [3].

It is highly desirable to apply suitable remedial approaches to polluted soil, which can reduce the risk of metal contamination. The excavation and disposal of soil are no longer considered to be a permanent solution. The demand for soil treatment techniques is consequently growing and the development of new low-cost, efficient and environmentally friendly remediation technologies has generally become one of the key research activities in environmental science and technology. In selecting the most appropriate soil remediation methods for a particular polluted site, it is of paramount importance to consider the characteristics of the soil and the contaminants [4] [5].

Soil remediation techniques include: 1) ex-situ (excavation) or in-situ (on-site) soil washing with chemical agents, 2) chemical immobilization/stabilization method to reduce the solubility of heavy metals by adding some non-toxic materials into the soils, 3) electrokinetics (electromigration), 4) covering the original polluted soil surface with clean soils, 5) dilution method (mixing polluted soils with surface and subsurface clean soils to reduce the concentration of heavy metals), 6) phytoremediation by plants such as woody trees [6]-[10].

Soil washing technology using particle size separation and chemical extraction with aqueous solutions of surfactants and mineral acids is in full-scale use [4] [5] [11]. Soil washing is particularly frequently used in soil remediation because it: 1) completely removes the contaminants, hence ensures the rapid cleanup of a contaminated site [10] [12], 2) meets specific criteria, 3) reduces or eliminates long-term liability, 4) may be the most cost-effective solution and 5) may produce recyclable material or energy [6] [10].

With chemical soil washing, soil particles are cleaned by selectively transferring the contaminants from the soil into solution [10] [13]. The effectiveness of washing is closely related to the ability of the extracting solution to dissolve the metal contaminants in soils. However, the strong bonds between the soil and metals make the cleaning process difficult. Therefore, only extractants capable of optimally dissolving the metals must be carefully sought during soil washing. Acids, surfactants, electrolytes and chelating agents can be used in soil washing technique [10] [14].

The efficiency of metal removal depends mainly on soil and metal characteristics (e.g. crystalline, solubility), extractant chemistry and processing conditions [5] [15] [16].

Strong acids attack and degrade the soil crystalline structure at extended contact times. For less damaging washes, organic acids and chelating agents are often suggested as alternatives to straight mineral acid use [10] [17].

The objectives of the present study are 1) to determine the effectiveness of AA in reducing the concentrations of lead, cadmium and nickel in soils to acceptable levels and 2) to investigate factors influencing desorption of these metals. AA is commonly known as moderate and weak chelating agents (low molecular weight organic acid). The potential of this organic acid to decontaminate a sandy soil (with a heavy metal concentration of 500 $\mathrm{mg} \cdot \mathrm{kg}^{-1}$ ) was studied.

\section{Experimental}

\subsection{Soil Characterization and Tests}

Karbalaa's soil (from Karbalaa Governorate-south of Iraq) was used in the present study. The soil passing through $2 \mathrm{~mm}$ mesh, Samples were tested for measurement of particle size distribution, porosity, permeability coefficient, $\mathrm{pH}$, cation exchange capacity, Electrical conductivity, organic carbon, and organic matter. The measured physical and chemical properties of the soil are shown in Table 1.

\subsubsection{Particle Size Distribution}

The particle size distribution was obtained by using mechanical sieve analysis.

\subsubsection{Soil Porosity}

The porosity of the soil was determined by measuring the weight of a sample of dry sand, the weight of the 
Table 1. Characteristics of the studied soil.

\begin{tabular}{cc}
\hline Soil properties & Value \\
\hline Particle size distribution & \\
(ASTM D 422) & 97 \\
Sand (\%) & 3 \\
Silt (\%) & 0 \\
Clay (\%) & 7.4 \\
pH & 2.67 \\
Specific Gravity (g/ $\left./ \mathrm{cm}^{3}\right)$ & 0.073 \\
Carbon content $(\%)$ & 0.216 \\
Organic matter content $(\%)$ & 3.6 \\
Cation exchange capacity (CEC), $(\mathrm{meq} / 100 \mathrm{~g})$ & 2195 \\
Electrical conductivity (EC), $(\mu \mathrm{S} / \mathrm{cm})$ & $2.43 \times 10^{-3}$ \\
permeability coefficient $\left(\mathrm{cm} \cdot \mathrm{s}^{-1}\right)$ & 0.345 \\
Porosity &
\end{tabular}

saturated sample submerged in water, the volume of sample, and temperature of the water using the following equation [18]:

$$
\begin{gathered}
n=\frac{v_{v}}{v} \\
v_{v}=\frac{W_{s}-W_{d}}{\rho_{w}}
\end{gathered}
$$

where:

$n=$ porosity.

$v_{v}=$ voids volume $\left(\mathrm{L}^{3}\right)$.

$v=$ total volume of sample $\left(\mathrm{L}^{3}\right)$.

$W_{s}=$ weight of the saturated water sample $(\mathrm{M})$.

$W_{d}=$ weight of the dry sample (M).

$\rho_{w}=$ density of the water $\left(\mathrm{M} / \mathrm{L}^{3}\right)$.

The bulk density of the dry soil is $1.6 \mathrm{~g} / \mathrm{cm}^{3}$. The porosity ( $n$ ) was found to be 0.345 .

\subsubsection{Soil Permeability}

The permeability coefficient is a constant of proportionality relating to the ease with which a fluid passes through a porous medium [19]. The method of constant head test (ASTM D2434-68) was used for measuring permeability. The testing was under temperature $20^{\circ} \mathrm{C}$. The average value of the measured permeability coefficient was found to be $\left(2.43 \times 10^{-3}\right) \mathrm{cm} / \mathrm{s}$.

\subsection{4. $\mathrm{pH}$ Measurement}

Soil $\mathrm{pH}$ is the amount of free hydrogen $\left(\mathrm{H}^{+}\right)$ions in water; it represents the active acidity. Soil $\mathrm{pH}$ was measured in a 1:10 (w/v) ratio of soil to distilled water using a pH-meter (HANNA HI 98150). The potential acidity is the amount of $\mathrm{H}^{+}$ions tied to the absorbing complex. It was measured in a 1:10 (w/v) ration of soil to solution of 1 $\mathrm{M} \mathrm{KCl}$ and it is due to $\mathrm{H}^{+}$exchangeable [20] [21].

\subsubsection{Cation Exchange Capacity}

The CEC is the maximum amount of cations that $100 \mathrm{~g}$ of dry soil can absorb. It was determined using the method of $\mathrm{CH}_{3} \mathrm{COONH}_{4}\left(1 \mathrm{M}\right.$, pH 7). Thirty $\mathrm{ml}$ of $1 \mathrm{M} \mathrm{CH}_{3} \mathrm{COONH}_{4}$ were added to $5 \mathrm{~g}$ of soil. The suspension was shaken for 2 hours and then centrifuged for $15 \mathrm{~min}$. After centrifugation and filtration, the filtrate was transferred into a $100 \mathrm{ml}$ flask and two other volumes of $30 \mathrm{ml}$ ammonium acetate were added successively after 
$30 \mathrm{~min}$ of agitation and centrifugation. The final filtrates were completed to $100 \mathrm{ml}$ with ammonium acetate solution [20].

\subsubsection{Soil Organic Carbon}

The presence of organic carbon increases the cation exchange capacity of the soil. Organic carbon was measured using modified Walker-Black method [20] [22].

\subsubsection{Soil Organic Matter}

The organic matter content in soil samples was determined by multiplying the organic carbon content by 1.724 (using the assumption that organic matter contains approximately 58\% carbon) as shown in Equation (3).

$$
\% \text { Organic matter }=(\% \text { total } C \times 1.72) / 0.58
$$

\subsection{Apparatus}

Normal laboratory glassware (borosilicate), polyethylene vessels, a pH meter, a flask shaker (Gesellschaft for Labortechnik, mbH, D-30938 Burgwedel, Type 3015, Germany) and a centrifuge (MSE, Minette, Serial No. 9 71, England) were used. A flame atomic absorption spectrometry AAS (SENSAA, GBC Scientific equipment, Australia) was used for metal assay.

\subsection{Soil Preparation}

Soil samples were artificially contaminated with aqueous solutions of lead nitrate $\left[\mathrm{Pb}\left(\mathrm{NO}_{3}\right)_{2}\right]$, cadmium nitrate $\left[\mathrm{Cd}\left(\mathrm{NO}_{3}\right)_{2} \cdot 4 \mathrm{H}_{2} \mathrm{O}\right]$ and nickel nitrate $\left[\mathrm{N}_{2} \mathrm{NiO}_{6} \cdot 6 \mathrm{H}_{2} \mathrm{O}\right] .0 .5 \mathrm{~L}$ of $1000 \mathrm{mg} / \mathrm{L}$ of the metal stock was added to 1000 $\mathrm{g}$ of the parent soil. The above spiking was intended to furnish about $500 \mathrm{mg} / \mathrm{kg}$ as target concentration. After the preparation of the contaminant-spiked soil, it was placed in sealed glass bottles and refrigerated. The soil was equilibrated for at least 2 weeks.

\subsection{Soil Washing Experiments}

Batch extractions of heavy metal contaminants using AA extractant concentrations of 0.001, 0.005, 0.01, 0.05, $0.1 \mathrm{~mol} / \mathrm{L}$ were conducted in $250 \mathrm{~mL}$ conical flasks. Each flask contained $1 \mathrm{~g}$ of soil and $10 \mathrm{~mL}$ of AA (1:10 solid/liquid ratio) was agitated using Shaker at a speed of $180 \mathrm{rpm}$ at room temperature for different times (15, 30, 60, 120, $180 \mathrm{~min}$ ). The suspensions were centrifuged by centrifuge at $3000 \mathrm{rpm}$ for $10-15 \mathrm{~min}$ and the supernatants were then filtered through filter paper for heavy metal analysis. The concentrations of metals were measured by AAS.

The percent of each metal removed were calculated using the following equation [23]:

$$
\text { Percent of metal removed }(\%)=\frac{C_{1} V_{1}}{C_{s} m_{s}} \times 100
$$

where $C_{1}$ and $C_{s}$ are the concentrations of metal in supernatant (in $\mathrm{mg} / \mathrm{L}$ ) and soil (mg/kg), respectively; $V_{1}$ is the volume of supernatant (in L) and $m_{s}$ is the dry mass of the soil (in $\mathrm{kg}$ ).

Lead, cadmium and nickel were extracted by washing with aqueous solutions of AA. Five selected AA concentrations $(0.001,0.005,0.01,0.05$, and $0.1 \mathrm{~mol} / \mathrm{L})$ were tested. In the tests different contact times $(15,30,60$, $120,180 \mathrm{~min}$ ) were adopted, in order to evaluate the optimal conditions for the heavy metals extraction.

\section{Results and Discussion}

\subsection{Effect of Acetic Acid Concentration}

Different concentrations of AA were used and the extraction results are shown in Figure 1. The removal of $\mathrm{Pb}$, Cd increased with increasing AA concentration from 0.001 to $0.1 \mathrm{~mol} / \mathrm{L}$. No $\mathrm{pH}$ adjustment was made in the experiments of soil extraction.

At shacking time $3 \mathrm{hrs}$ the removal of $\mathrm{Pb}$ varies from $42.2 \%$ - 100\%, Cd removal efficiency varies from 5.2\% - $31.1 \%$ with increase concentration of AA, while the removal efficiency of $\mathrm{Ni}$ was not exceed $1 \%$. Comparing 


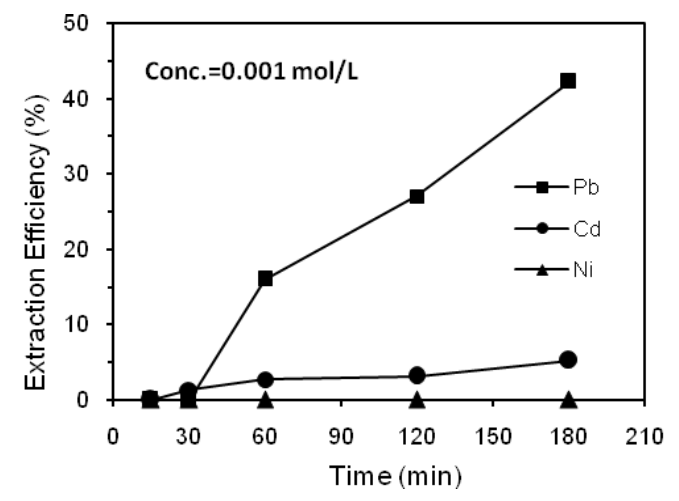

(a)

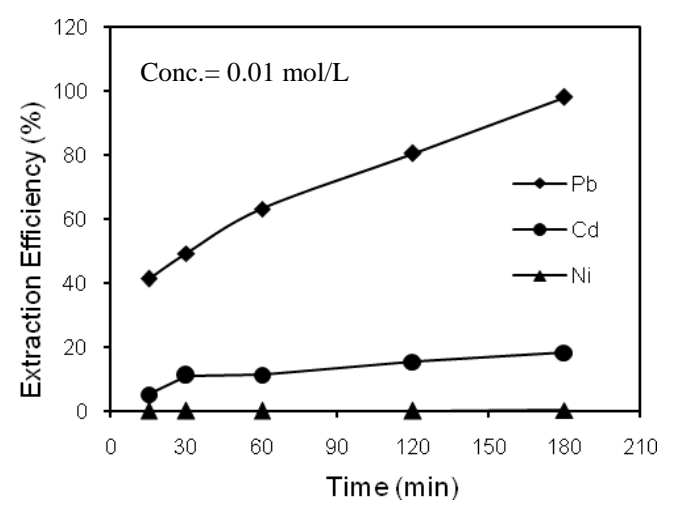

(c)

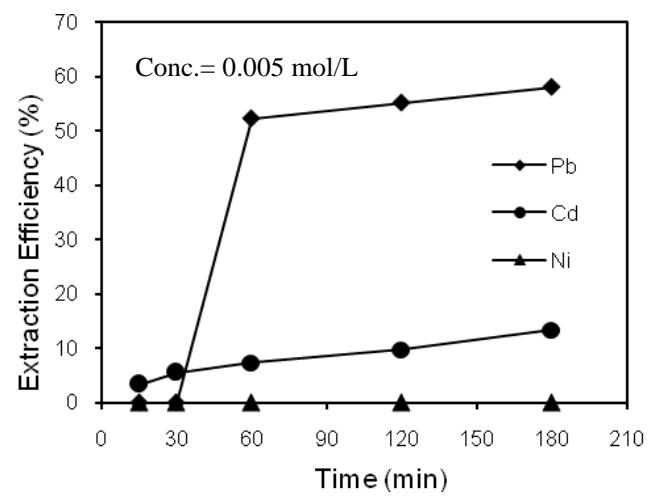

(b)

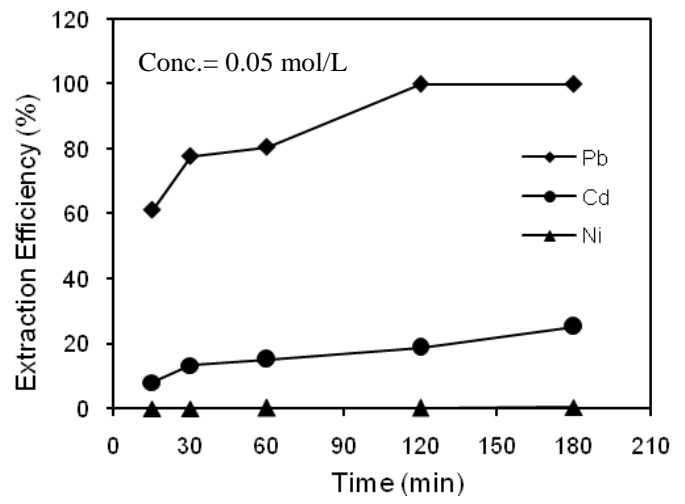

(d)

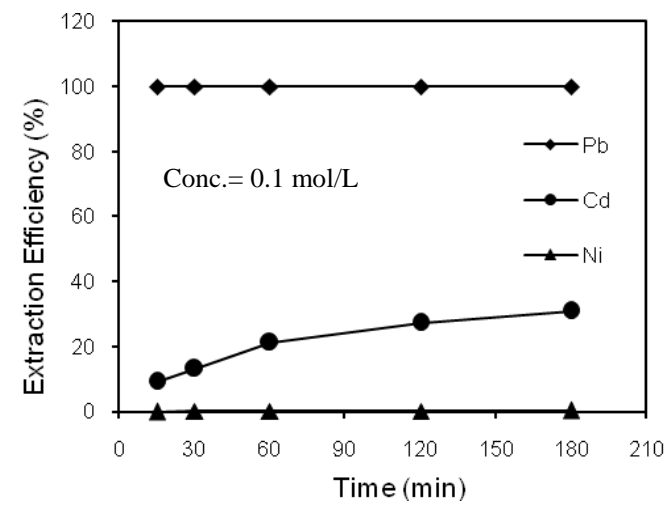

(e)

Figure 1. Removal of metals as a function of time; at concentration. (a) $0.001 \mathrm{~mol} / \mathrm{L}$; (b) $0.005 \mathrm{~mol} / \mathrm{L}$; (c) $0.01 \mathrm{~mol} / \mathrm{L}$; (d) $0.05 \mathrm{~mol} / \mathrm{L}$; (e) $0.1 \mathrm{~mol} / \mathrm{L}$.

with $\mathrm{Pb}$ and $\mathrm{Cd}$, the removal efficiency of $\mathrm{Ni}$ was very low. From these results, it can be concluded that the solubility of $\mathrm{Ni}$ in AA was very low.

As observed, efficiency is different in the mentioned soil with the different concentrations of AA especially for $\mathrm{Cd}$ and $\mathrm{Ni}$, however, the remediation efficiency is maximum for $\mathrm{Pb}$. The results indicated that the acid solution is effective in removing $\mathrm{Pb}$ and moderately effective in removing $\mathrm{Cd}$ from contaminated soils, this technique failed to reduce Ni. It was found that $0.1 \mathrm{~mol} / \mathrm{L}$ AA for soil washing was effective in removing absorbed $\mathrm{Pb}$ from contaminated soil (100\% efficiency) at time $15 \mathrm{~min}$. While the efficiency reaching $100 \%$ with washing solution of 0.05 and $0.01 \mathrm{~mol} / \mathrm{L}$ at times 120 and $180 \mathrm{~min}$, respectively. The removal efficiency of Cd was ranging from $0 \%$ to $9.3 \%, 1.3 \%$ to $13.4 \%, 2.7 \%$ to $21.3 \%, 3.1 \%$ to $27.3 \%$ and $5.2 \%$ to $31.1 \%$ at times $15,30,60$, 120 and 180 min respectively. This means that the maximum removal of Cd was 31.1 at time 180 min. The re- 
moval efficiency of Ni was $\approx 1 \%$.

High concentrations achieved acidic medium which is essential for the movement of pollutants and ease of transmission and exchange of ions with washing solution. This was expected, according to [24] the higher concentrations of extractant in soil, the greater availability of extraction. [25] mentioned that metal removal increased with increasing the extractant concentration, this may due to the soil's properties,such as metals distribution and physicochemical forms in the soil.

\subsection{Kinetics of Metal Extraction}

In order to comprehend the washing process and determine the best conditions for contaminants removal, a kinetic study was undertaken by washing soil with five concentrations of AA solution and the extraction rates for metals were measured. The extraction of lead is completely removed from soil, at times ranging from 15 to 180 min, removal efficiency was increased from $0 \%$ to $42.2 \%, 0 \%$ to $58 \%, 41.2 \%$ to $98 \%, 61.3 \%$ to $100 \%$ and $100 \%$; at concentration $0.001,0.005,0.01,0.05$ and $0.1 \mathrm{~mol} / \mathrm{L}$, respectively. Cadmium extractions were $0 \%$ to $5.2 \%$, $3.4 \%$ to $13.4 \%, 5.2 \%$ to $18.1 \%, 8.1 \%$ to $25.3 \%$ and $9.3 \%$ to $31.1 \%$; at the same range of concentrations above. Nickel extraction was very low and equal to about $1 \%$. The removal efficiencies of lead and cadmium were increased with time. Comparing to lead and cadmium the nickel removal efficiency was insignificant with time.

From Figure 1(e) it is obvious that $15 \mathrm{~min}$ of mixing and $0.1 \mathrm{~mol} / \mathrm{L}$ AA concentration are enough for complete lead extraction. Extraction can be completed at time 120 min when concentration $0.05 \mathrm{M}$ Figure 1(d). When a large amount of extractant became exhausted, the extraction rate is controlled by the rate at which the extractant is transported from the soil exterior to interior sites of the extractant, because buffering capacity for soil reaching equilibrium. Metal removal efficiency by chemical extraction process depends on soil geochemistry (soil texture, cation exchange capacity, organic matter, particle size, and large surface area of contaminated soils allow extract of pollutants).

The removal percentage increases as the contact time increase and remains constant after reaching the equilibrium, this agreed with [24].

\subsection{Effect of $0.5 \mathrm{~mol} / \mathrm{L}$ and $1.0 \mathrm{~mol} / \mathrm{L} \mathrm{AA}$ on Cadmium and Nickel Removal Efficiency}

The extraction capacities of AA, in all concentrations used, are less than $48.3 \%$ for $\mathrm{Cd}$ and very low for $\mathrm{Ni}$ (less than 1.0\%), but the results are improved when AA concentration increases. For this reason $0.5 \mathrm{~mol} / \mathrm{L}$ and 1.0 $\mathrm{mol} / \mathrm{L}$ AA as soil washing solutions at $\mathrm{pH} 4$ are investigated as shown in Figure 2. At time 3 hrs the greater removal efficiency for these two metals was at concentration $1 \mathrm{~mol} / \mathrm{L}$. The best extraction of cadmium and nickel were $70.6 \%$ and 23.3 respectively. The difference between the extraction efficiencies of $0.5 \mathrm{~mol} / \mathrm{L}$ and $1 \mathrm{~mol} / \mathrm{L}$ was ranging from $14.53 \%$ to $36.2 \%$ for cadmium and from $28.33 \%$ to $39.88 \%$ for nickel.

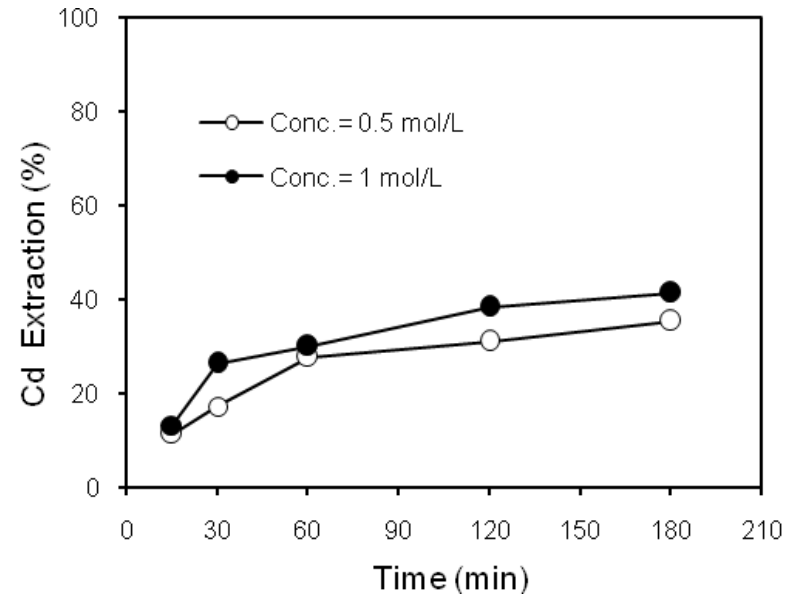

(a)

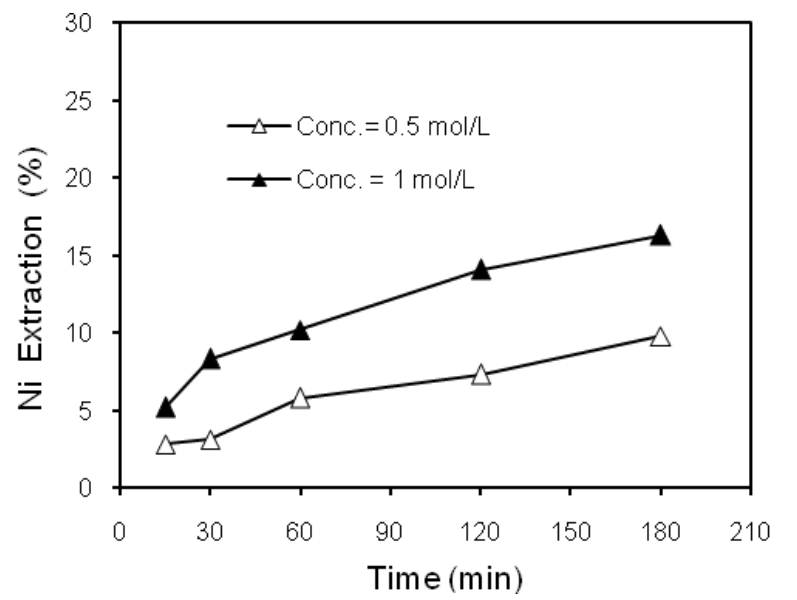

(b)

Figure 2. Comparison between the removal percentage at $0.5 \mathrm{~mol} / \mathrm{L}$ and $1.0 \mathrm{~mol} / \mathrm{L}$ of AA for (a) cadmium; (b) nickel, as a function of time. 


\section{Conclusion}

Effectiveness of acetic acid to the removal of lead, cadmium and nickel from contaminated soil was examined in the soil washing processing. The removal efficiencies of these metals with acetic acid were increased with increasing extractant concentration. High extraction efficiency was achieved for $\mathrm{Pb}$ with acetic acid even at the lowest concentration and time. The acid solution was moderately effective in removing Cd. Comparing to lead and cadmium the nickel removal efficiency was insignificant with time, acetic acid was found to be very weak extractant to release $\mathrm{Ni}(\sim 1 \%)$ at concentration less than $0.1 \mathrm{~mol} / \mathrm{L}$. In general the efficiencies of Cd and $\mathrm{Ni}$ removal were improved with $1 \mathrm{~mol} / \mathrm{L}$ acetic acid solution.

\section{References}

[1] Niinae, M., Nishigaki, K. and Aoki, K. (2008) Removal of Lead from Contaminated Soils with Chelating Agents. Materials Transactions, 49, 2377-2382. http://dx.doi.org/10.2320/matertrans.M-MRA2008825

[2] Bohn, H.L., McNeal, B.L. and O’Connor, G.A. (1979) Soil Chemistry. Wiley, New York.

[3] Tandy, S., Bossart, K., Mueller, R., Ritschel, J., Hauser, L., Schulin, R. and Nowack, B. (2004) Extraction of Heavy Metals from Soils Using Biodegradable Chelating Agents. Environmental Science and Technology, 38, 937-944. http://dx.doi.org/10.1021/es0348750

[4] Kuhlman, M.I. and Greenfield, T.M. (1999) Simplified Soil Washing Processes for Variety of Soils. Journal of Hazardous Materials, 66, 31-45. http://dx.doi.org/10.1016/S0304-3894(98)00212-X

[5] Mann, M.J. (1999) Full-Scale and Pilot-Scale Soil Washing. Journal of Hazardous Materials, 66, 119-136. http://dx.doi.org/10.1016/S0304-3894(98)00207-6

[6] GOC (2003) Site Remediation Technologies: A Reference Manual. Contaminated Sites Working Group, Ontario, Chapter 6.

[7] Fawzy, E.M. (2008) Soil Remediation Using In-Situ Immobilization Techniques. Chemistry and Ecology, 24, $147-156$. http://dx.doi.org/10.1080/02757540801920154

[8] Nouri, J., Khorasani, N., Lorestani, B., Karami, M., Hassani, A.H. and Yousefi, N. (2009) Accumulation of Heavy Metals in Soil and Uptake by Plant Species with Phytoremediation Potential. Environmental Earth Sciences, 59, 315-323. http://dx.doi.org/10.1007/s12665-009-0028-2

[9] Kord, B., Mataji, A. and Babaie, S. (2010) Pine (Pinus eldarica Medw.) Needles as Indicator for Heavy Metals Pollution. International Journal of Environmental Science and Technology, 7, 79-84. http://dx.doi.org/10.1007/BF03326119

[10] Wuana, R.A., Okieimen, F.E. and Imborvungu, J.A. (2010) Removal of Heavy Metals from a Contaminated Soil Using Organic Chelating Acids. International Journal of Environmental Science and Technology, 7, 485-496. http://dx.doi.org/10.1007/BF03326158

[11] Pearl, M., Pruijn, M. and Bovendeur, J. (2006) The Application of Soil Washing to the Remediation of Contaminated Soils. Land Contamination \& Reclamation, 14, 713-726.

[12] Wood, P. (1997) Remediation Methods for Contaminated Sites. In: Hester, R. and Harrison, R., Eds., Contaminated Land and Its Reclamation, Royal Society of Chemistry, Cambridge, 47-71.

[13] Nwuche, C.O. and Ugoji, E.O. (2008) Effects of Heavy Metal Pollution on the Soil Microbial Activity. International Journal of Environmental Science and Technology, 5, 409-414. http://dx.doi.org/10.1007/BF03326036

[14] Oustan, S., Heidari, S., Neyshabouri, M.R., Reyhanitabar, A. and Bybordi, A. (2011) Removal of Heavy Metals from a Contaminated Calcareous Soil Using Oxalic and Acetic Acids as Chelating Agents. International Conference on Environment Science and Engineering IPCBEE, 8, IACSIT Press, Singapore.

[15] Peters, W.R. (1999) Chelant Extraction of Heavy Metals from Contaminated Soil. Journal of Hazardous Materials, 66, 151-210. http://dx.doi.org/10.1016/S0304-3894(99)00010-2

[16] Moutsatsou, A., Gregou, M., Matsas, D. and Protonotarios, V. (2006) Washing as a Remediation Technology Applicable in Soils Heavily Polluted by Mining-Metallurgical Activities. Chemosphere, 63, 1632-1640. http://dx.doi.org/10.1016/j.chemosphere.2005.10.015

[17] Yu, J. and Klarup, D. (1994) Extraction Kinetics of Copper, Zinc, Iron, and Manganese from Contaminated Sediment Using Disodium Ethylenediaminetetraacetate. Water, Air, \& Soil Pollution, 75, 205-225.

[18] Gzar, H.A. (2010) Experimental Investigation and Numerical Modeling of Benzene Dissolution and Transport in a Saturated Zone of the Soil. Ph.D. Thesis, University of Baghdad, Baghdad.

[19] Bowles, J.E. (1978) Engineering Properties of Soils and Their Measurement. McGraw-Hill Kogakusha, Ltd., Tokyo.

[20] Yobouet, Y.A., Adouby, K., Trokourey, A. and Yao, B. (2010) Cadmium, Copper, Lead and Zinc Speciation in Con- 
taminated Soils. International Journal of Engineering Science and Technology, 2, 802-812.

[21] Chatain, V. (2004) Characterization of the Potential Mobilization of Arsenic and Other Inorganic Constituents in Soils from a Gold Mining Site. Ph.D. Dissertation, National Institute of Applied Science of Lyon, Lyon.

[22] CEAEQ (2003) Determination of Organic Matter by Determination of Organic Carbon in Agricultural Soils by Method of Walkley-Black's Modified Method. MA. 1010-WB 1.0. Ministry of Environment of Quebec.

[23] Reddy, K.R. and Chinthamreddy, S. (2000) Comparison of Extractants for Removing Heavy Metals from Contaminated Clayey Soils. Soil and Sediment Contamination, 9, 449-462. http://dx.doi.org/10.1080/10588330091134347

[24] Mohanty, B. and Mahindraker, A.B. (2011) Removal of Heavy Metals by Screening Followed by Soil Washing from Contaminated Soil. International Journal of Technology and Engineering System (IJTES), 2, 290-293.

[25] Kirpichtchikova, T.A., Manceau, A., Spadini,L., Panfili, F., Marcus, M.A. and Jacquet, T. (2006) Speciation and Solubility of Heavy Metals in Contaminated Soil Using X-Ray Microfluorescence, EXAFS Spectroscopy, Chemical Extraction, and Thermodynamic Modeling. Geochimica et Cosmochimica Acta, 70, 2163-2190.

http://dx.doi.org/10.1016/j.gca.2006.02.006 
Scientific Research Publishing (SCIRP) is one of the largest Open Access journal publishers. It is currently publishing more than 200 open access, online, peer-reviewed journals covering a wide range of academic disciplines. SCIRP serves the worldwide academic communities and contributes to the progress and application of science with its publication.

Other selected journals from SCIRP are listed as below. Submit your manuscript to us via either submit@scirp.org or Online Submission Portal.
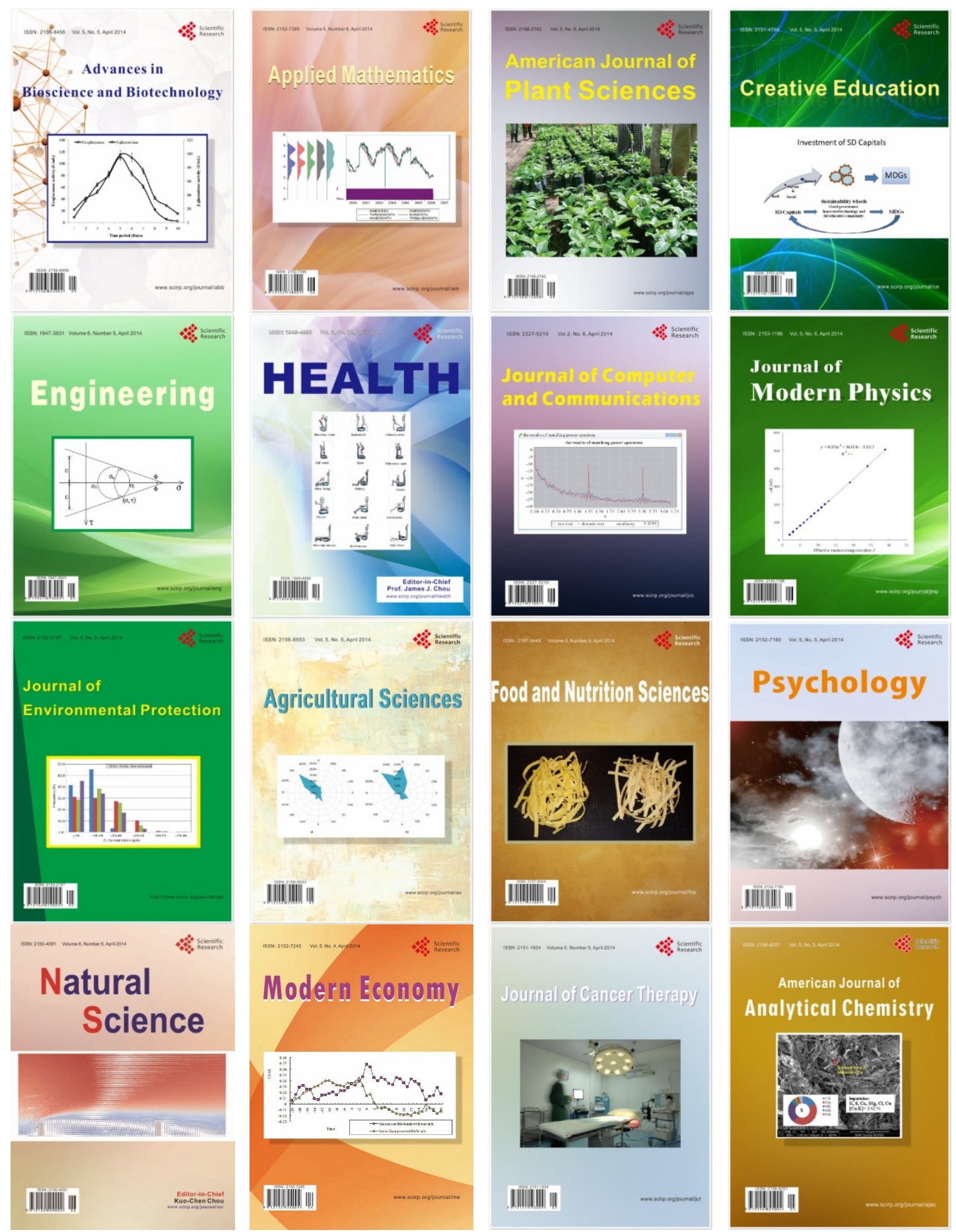